\title{
Biology and Economics of Recommendations for Insecticide-Based Management of Soybean Aphid
}

\begin{abstract}
Robert L. Koch, Department of Entomology, University of Minnesota, Saint Paul 55108; Bruce D. Potter, Southwest Research and Outreach Center, University of Minnesota, Lamberton 56152; Phillip A. Glogoza, University of Minnesota Extension, Moorhead 56560; Erin W. Hodgson, Department of Entomology, lowa State University, Ames 50011; Christian H. Krupke, Department of Entomology, Purdue University, West Lafayette, IN 47907; John F. Tooker, Department of Entomology, Penn State University, University Park 16802; Christina D. DiFonzo, Department of Entomology, Michigan State University, East Lansing 48824; Andrew P. Michel and Kelley J. Tilmon, Department of Entomology, The Ohio State University, Wooster 44691; Travis J. Prochaska, North Central Research Extension Center, North Dakota State University Extension, Minot 58701; Janet J. Knodel, Department of Plant Pathology, North Dakota State University, Fargo 58102; Robert J. Wright, Department of Entomology, University of Nebraska-Lincoln 68583; Thomas E. Hunt, Department of Entomology, University of Nebraska-Lincoln, Concord 68728; Bryan Jensen, Integrated Pest Management, University of Wisconsin, Madison 53706; Adam J. Varenhorst, Agronomy, Horticulture, and Plant Science Department, South Dakota State University, Brookings 57006; Brian P. McCornack, Department of Entomology, Kansas State University, Manhattan 66506; Kelly A. Estes and Joseph L. Spencer, Illinois Natural History Survey, University of Illinois, Champaign 61820
\end{abstract}

Accepted for publication 13 December 2016.

\section{ABSTRACT}

Soybean aphid, Aphis glycines Matsumura, remains the key insect pest of soybean, Glycine max (L.) Merrill, in the north-central United States. Management of this pest has relied primarily on scouting and application of foliar insecticides based on an economic threshold (ET) of 250 aphids per plant. This review explains why this ET remains valid for soybean aphid management, despite changes in

\section{INTRODUCTION}

The soybean aphid, Aphis glycines Matsumura (Fig. 1), was first detected in the United States in 2000. Prior to the invasion by this pest, insecticide applications to soybean, Glycine max (L.) Merrill, in the north-central United States were rare (USDANASS 1999), but during the last region-wide outbreak in 2005, millions of acres were treated for soybean aphid (USDA-NASS 2005). Although outbreaks are less common in some states since the mid-2000s (Bahlai et al. 2015), soybean aphid is still the key insect pest of soybean in this region (Hurley and Mitchell 2014). In North America, a tremendous amount of research and observational data have been generated on soybean aphid since its initial detection, and tools and knowledge now exist for effective management of this pest (Hodgson et al. 2012; Ragsdale et al. 2004; Ragsdale et al. 2011; Tilmon et al. 2011).

Soybean aphid management recommendations, including the economic threshold (Ragsdale et al. 2007), developed by landgrant universities are based on replicated research evaluated by other agricultural scientists (i.e., peer-reviewed) before publication and dissemination. These recommendations take into consideration pest biology, as well as effectiveness and short- and longterm economic and environmental implications of management tactics. Economic conditions (e.g., crop and input prices) have changed since publication of soybean aphid management recommendations (Ragsdale et al. 2007; Tilmon et al. 2011). Here, we

Corresponding author: Robert L. Koch. Email: koch0125@umn.edu.

doi:10.1094/PHP-RV-16-0061

(C) 2016 The American Phytopathological Society crop value and input costs. In particular, we review how soybean aphid impacts soybean yield, the role of biology and economics in recommendations for soybean aphid management, and the shortand long-term consequences of inappropriately timed insecticide applications.

present a research-based review updating what is known about soybean aphid, including the potential effects on yield and costeffective management for this pest.

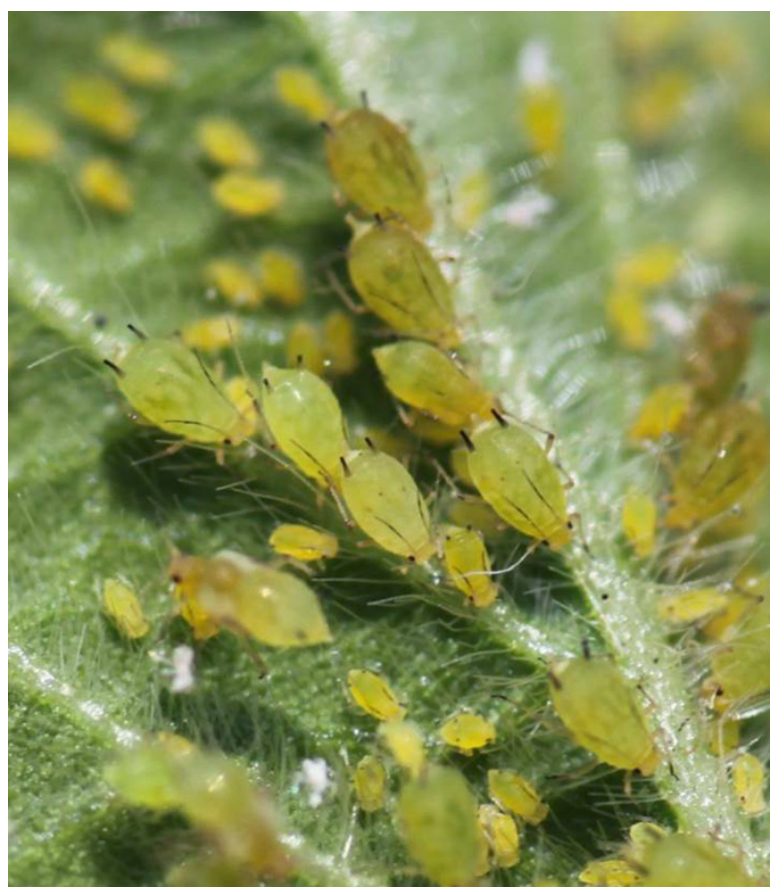

FIGURE 1

Soybean aphid colony on soybean (photo by A. Varenhorst). 


\section{SOYBEAN APHID INJURY TO SOYBEAN}

All aphids, including soybean aphid, feed on plant fluids by inserting piercing-sucking mouthparts directly into the phloem and removing water and nutrients (Pettersson et al. 2007), which can decrease photosynthetic rates of soybean (Macedo et al. 2003). To survive and reproduce, soybean aphids require specific nitrogen-rich amino acids that are present in plant fluids at low concentrations (Douglas and van Emden 2007; Mittler and Douglas 2003; Walter and DiFonzo 2007), which means they must ingest large quantities of plant fluids to fulfill their nutritional needs (Douglas and van Emden 2007). Nutrient (Myers et al. 2005; Myers and Gratton 2006; Walter and DiFonzo 2007) and moisture (Nachappa et al. 2016) status of soybean influences the composition of the plant fluids and, in turn, soybean aphid. In addition, quality of plant fluids likely influences location of soybean aphids within the canopy as plants age (McCornack et al. 2008). Excess water and sugars from the plant fluids are excreted by aphids as sticky waste (Malumphy 1997) called "honeydew," which accumulates on leaves of heavily infested plants. Sooty mold fungus (Fig. 2) can grow on honeydew-covered leaves, blocking sunlight and further interfering with photosynthesis (Malumphy 1997; Lemos Filho and Paiva 2006).

Feeding by soybean aphid on soybean can reduce plant growth, pod number, seed number, seed weight, and seed oil concentration (Beckendorf et al. 2008; Ragsdale et al. 2011). Prolonged infestations beginning early in the season can affect all soybean yield components, while later infestations tend to only reduce seed size (Beckendorf et al. 2008). Soybean aphid feeding can also facilitate population growth of soybean cyst nematode, Heterodera glycines Ichinhoe (McCarville et al. 2014), and transmit several disease-causing viruses of soybean (e.g., Soybean mosaic virus and Alfalfa mosaic virus) (Hill et al. 2001; Mueller and Grau 2007) and other crops (Davis et al. 2005; Davis and Radcliffe 2008; DiFonzo and Agle 2008; Wang et al. 2006). Because these soybean viruses are not currently recognized as consistent, signi-

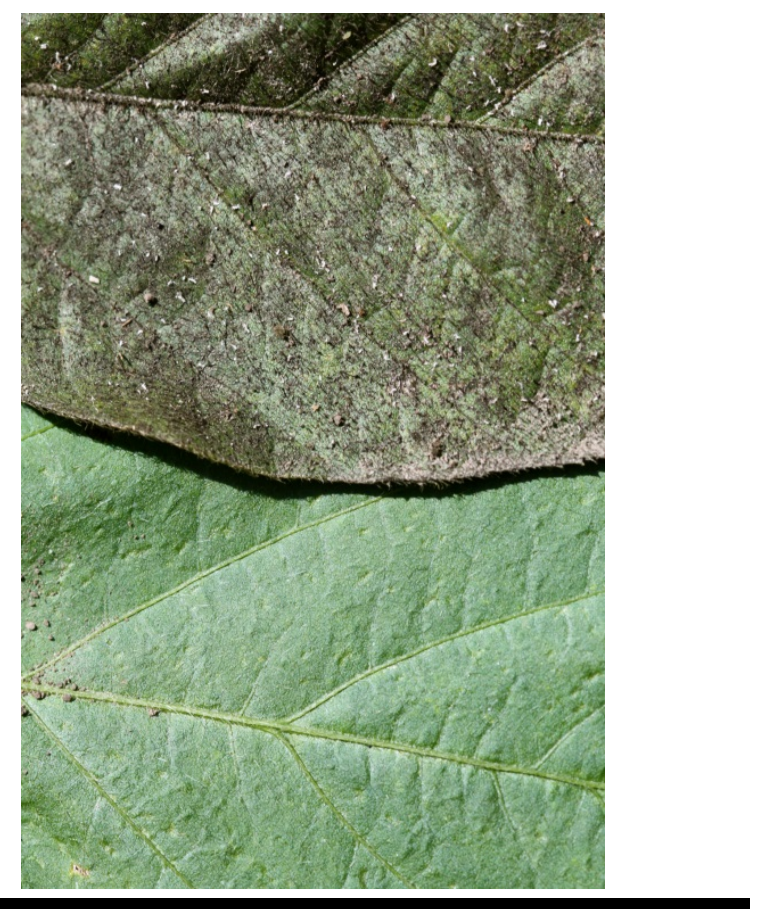

\section{FIGURE 2}

A clean soybean leaf (bottom) compared to a leaf from an aphidinfested plant (top) which is covered with honeydew and sooty mold (photo by B. McCornack). ficant threats to yield in the north-central United States, they are not accounted for in general soybean aphid management recommendations. Soybean aphids are not known to transmit fungal or bacterial diseases to soybean. However, soybean aphid and some pathogens may co-occur at similar times or be favored by similar environmental conditions, which may result in the incorrect assumption that a disease was transmitted by aphids or the pathogen entered the plant through feeding wounds caused by aphids. In reality, compared to defoliating insects, aphid feeding creates minimal wounding; plant cells along the feeding tracks generally are not damaged (Dixon 1998).

Yield loss from soybean aphid is a function of the number of aphids on the plant and the duration of their feeding (Ragsdale et al. 2007). With these two parameters, aphid population pressure over time can be calculated as cumulative aphid-days (Hanafi et al. 1989). For example, the population pressure of a single soybean aphid on a plant for 10 days is equal to 10 aphid-days (1 aphid $\times 10$ days), while that of 200 aphids on a plant for 20 days is equal to 4,000 aphid-days (200 aphids $\times 20$ days). The aphidday concept has proven to be a consistent indicator of how soybean yield responds to aphid populations (Ragsdale et al. 2007) and has been utilized for aphids in other crops (Kieckhefer et al. 1995).

\section{BIOLOGICAL AND ECONOMIC CONSIDERATIONS IN SOYBEAN APHID MANAGEMENT}

Reliable treatment decisions for soybean aphid start with field estimates of aphid densities (i.e., numbers of aphids per plant) (Hodgson et al. 2004). Soybean fields should be scouted on a regular basis because soybean aphid populations can increase rapidly (Hodgson et al. 2012; McCornack et al. 2004; Ragsdale et al. 2007), particularly when winged aphids migrate within and between fields (Costamagna et al. 2013). Early-season (i.e., May through mid-July) scouting should focus on fields that have histories of early colonization by soybean aphids, particularly early-planted fields and fields near buckthorn, Rhamnus spp., the overwintering host of soybean aphid (Bahlai et al. 2010). More fields should be scouted as soybean aphid populations develop throughout the growing season and plants begin to enter reproductive (R) stages. There may not be a need to visit every field every week, but enough fields should be checked to detect increasing aphid populations that require weekly sampling. NCSRP (2013) and Extension bulletins provide more detailed recommendations for scouting.

Treatment decisions for soybean aphid are based on the relationship between aphid pressure and damage. The lowest pest population that causes measurable yield loss is called the damage boundary, shown on a generalized damage curve in Figure 3. The damage boundary is a function of the interaction of the pest, crop, and environment and is independent of changing economic factors such as crop value and input costs (Pedigo et al. 1986). No quantifiable yield loss occurs while pest pressure remains below the damage boundary. For soybean aphid, the damage boundary is estimated at about 4,000 to 5,000 cumulative aphid-days (Ragsdale et al. 2007; Tilmon 2014). When the data for the yield-loss relationship for soybean as a function of aphid pressure (Ragsdale et al. 2007) are regressed over a range of 0 to 5,000 cumulative aphid-days no yield loss is detected with increasing aphid pressure $\left(y=-0.000005 x+1.0074, r^{2}=0.025\right.$, where $x$ is cumulative aphid-days and y is proportion maximum yield).

Further along the damage curve (Fig. 3) is the economic injury level (EIL), which is the point at which the yield loss from insect injury is equal to the cost of a management action, such as an 
insecticide application (Pedigo et al. 1986). At the EIL, an insecticide application is economically justified. The EIL considers the yield-loss relationship for the pest and crop, treatment costs and efficacy, and expected crop yields and value (Pedigo et al. 1986). In the case of soybean aphid on soybean, the EIL is approximately 5,500 cumulative aphid-days (Ragsdale et al. 2007).

To prevent a pest population from reaching the EIL, a triggerpoint or economic threshold (ET) is set to take action at a lower pest density (Pedigo et al. 1986). The ET can also be referred to as an action threshold or treatment threshold. For most insect pests the ET is set well below the EIL to minimize the chance of incurring economic loss. To more readily apply the aphid-yield loss relationship to field scouting and aphid management decisions, a value in terms of aphids per plant was calculated for use as the ET to apply an insecticide and to reduce the likelihood of a population reaching an EIL. For soybean through the R5 growth stage (Fehr and Caviness 1977), an ET of 250 soybean aphids per plant with more than $80 \%$ of plants infested and aphid populations increasing was established to prevent soybean aphid populations from reaching the EIL (see above), which has been calculated to occur at about 675 aphids per plant (Ragsdale et al. 2007). In fact, the ET for soybean aphid is also lower than the damage boundary (see above), which has been estimated to occur at 485 to 600 aphids per plant (Tilmon 2014).

To determine the values for the damage boundary, EIL and ET for soybean aphid, thousands of whole-plant aphid counts were taken at frequent intervals throughout the growing season, replicated over multiple years, and at multiple locations in multiple states (Ragsdale et al. 2007). The importance of factors other than pest abundance on relationships between pest populations and crop yields has been acknowledged (Pedigo et al. 1986). Such factors are implicitly incorporated into the ET for soybean aphid, because the large dataset used for its development incorporated a wide range of soybean growing environments, along with variation in plant growth stage, natural enemy abundance, moisture, and other stresses. Attempts have been made to explicitly account for variability in some of these factors for soybean aphid management; however, such dynamic thresholds are currently not recommended for soybean aphid management in the north-central United States. Catangui et al. (2009) developed EILs for soybean aphid on different soybean growth stages; however, the caged conditions under which their experiment was performed affected environment, biological control and aphid emigration, and limit the ability to implement their recommendations for soybean aphid management (O'Neal et al. 2010). ETs accounting for natural enemy abundance have also been developed (Hallet et al. 2014; Zhang and Swinton 2009; Zhang and Swinton 2012), but have not been adequately validated for implementation in the north-central United States. Further research to develop and validate such recommendations is encouraged.

In the decade since the establishment of ET for soybean aphid (Ragsdale et al. 2007), university-based research has continued to reconfirm the ET and damage boundary values for soybean aphid (Hodgson and VanNostrand 2014, 2015, 2016; Johnson et al. 2009). Although the EIL may vary based on changing value of soybean or insecticide costs, no consistent economic gain can be found with a reduced ET for soybean aphid. This is because the ET of 250 aphids per plant is already set well below the damage boundary, so no measurable yield loss occurs at this soybean aphid population level.

\section{COSTS ASSOCIATED WITH TREATING SOYBEAN APHIDS TOO EARLY}

The ET for soybean aphid is best viewed as a fixed action or treatment threshold. In the case of soybean aphid, using a higher ET reduces the lead-time for insecticide applications and increases risk of exceeding the EIL from rapidly increasing aphid populations. In contrast, using a lower ET may provide more lead-time for insecticide applications, but curtails the opportunity for natural enemies and environmental conditions to suppress soybean aphid populations. In addition, lowering the ET also has the potential to result in wasted insecticide applications, by treating fields that will never approach the EIL. Unlike the longestablished 250-aphid benchmark, both higher and lower ET's have not been adequately validated in field settings. Therefore, a sliding scale for the ET currently cannot be recommended for soybean aphid management.

While some newer insecticides target a narrower range of insects (Knodel et al. 2016; Tran et al. 2016; Varenhorst and O'Neal 2012), most insecticides used for soybean aphid management in the north-central United States are broad-spectrum organophosphates and pyrethroids (Hodgson et al. 2012; Olson et al. 2008). These non-specific insecticides not only kill aphids, but also kill beneficial insects (e.g., lady beetles, minute pirate bugs,

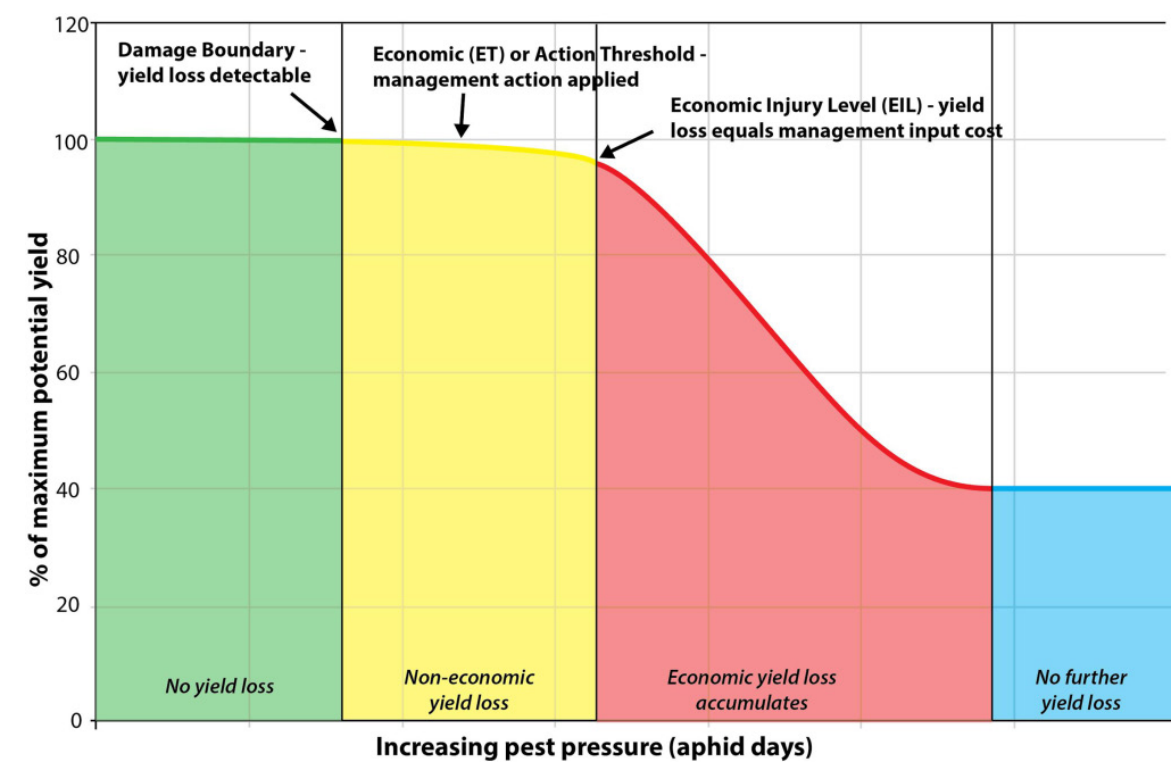

FIGURE 3

Damage curve showing a generalized relationship between pest population and crop yield (modified from Pedigo et al. 1986). 
parasitic wasps) that naturally suppress soybean aphid populations. In the absence of these beneficial insects soybean aphid populations may rebound, sometimes increasing to levels greater than before treatment. The cost of an additional insecticide application to control a rebounding soybean aphid population further narrows profit margins. By using the ET to make management decisions, a robust suite of beneficial insects has a chance to suppress soybean aphid populations and possibly prevent aphids from reaching the EIL.

Protection offered by early applications of insecticides may be overestimated. After application, insecticide residues will kill insects for varying lengths of time, but often only a few days and insecticide activity declines over time. Most insecticides registered for soybean aphid management are not systemic, so soybean foliage emerging after the insecticide application is not protected from immigrating aphids. Foliar applications of systemic insecticides, such as neonicotinoids, are absorbed by plants and typically move (i.e., translocated) upward to a limited extent within the plants (Buchholz and Nauen 2002; Nauen et al. 1999; Weichel and Nauen 2003). However, this translocation of insecticide to unsprayed foliage may be insufficient to suppress pest populations (Derksen et al. 2015).

Early treatment reduces or eliminates the cost efficiencies of a single, well-timed threshold-based treatment (Johnson et al. 2009). Furthermore, there are additional long-term costs of spraying too early or too often. For example, insecticide resistance has developed in other aphid species (Foster et al. 2007) and was documented in soybean aphid in Asia (Wang et al. 2011). More concerning, field-level failures of pyrethroid insecticides against soybean aphid were recently reported in Minnesota (Koch and Potter 2016).

\section{CONCLUSIONS}

To minimize the risk of an unnecessary insecticide application, it is important to consider the messenger and source of information related to pest management recommendations. The recommendations reviewed here are based on replicated, peer-reviewed research and successfully implemented over millions of acres for more than a decade. Changing economics may affect the EIL for soybean aphid, but it is prudent to remember that the ET of 250 aphids per plant is conservative and remains valid, because this value is far lower than the damage boundary. Although many generic insecticides are touted as inexpensive insurance compared to other inputs, they do not consistently provide a return on investment when used prophylactically. In large farming operations, a few dollars per acre for an additional input can add up quickly. Preemptive, insurance-type insecticide applications made at very low aphid densities carry well-documented pitfalls, including development of insecticide resistance and outbreaks of secondary pests such as spider mites. Furthermore, tank mixing an insecticide with an herbicide, fungicide, or liquid fertilizer application may result in reduced effectiveness, because the optimum timing or method of application for the tank-mix partners may differ. Using the ET, based on sound, peer-reviewed research will guide investment of crop-input dollars to where they are most likely to produce a positive return on investment, and minimize the chances of unintended adverse consequences.

\section{LITERATURE CITED}

Bahlai, C. A., Sikkema, S., Hallet, R. H., Newman, J., and Schaafsma, A. W. 2010. Modeling distribution and abundance of soybean aphid in soybean fields using measurements from the surrounding landscape. Environ. Entomol. 39:50-56.
Bahlai, C. A., van der Werf, W., O'Neal, M., Hemerik, L., and Landis, D. A. 2015. Shifts in dynamic regime of an invasive lady beetle are linked to the invasion and insecticidal management of its prey. Ecol. Appl. 25:18071818.

Beckendorf, E. A., Catangui, M. A., and Riedell, W. E. 2008. Soybean aphid feeding injury and soybean yield, yield components, and seed composition. Agron. J. 100:237-246.

Buchholz, A., and Nauen, R. 2002. Translocation and translaminar bioavailability of two neonicotinoid insecticides after foliar application to cabbage and cotton. Pest Manag. Sci. 58:10-16.

Catangui, M. A., Beckendorf, E. A., and Riedell, W. E., 2009. Soybean aphid population dynamics, soybean yield loss, and development of stagespecific economic injury levels. Agron. J. 101:1080-1092.

Costamagna, A. C., McCornack, B. P., and Ragsdale, D. W. 2013. Alate immigration disrupts soybean aphid suppression by predators. J. Appl. Ecol. 137:317-320.

Davis, J. A., Radcliffe, E. B., and Ragsdale, D. W. 2005. Soybean aphid, Aphis glycines Matsumura, a new vector of Potato virus $Y$ in potato. Amer. J. Potato Res. 82:197-201.

Davis, J. A., and Radcliffe, E. B. 2008. The importance of an invasive aphid species in vectoring a persistently transmitted potato virus: Aphis glycines is a vector of Potato leafroll virus. Plant Dis. 92:1515-1523.

Derksen, R. C., Canas, L. A., Ranger, C. M., and Reding, M. E. 2015. The effect of application method on the temporal and spatial distribution of neonicotinoid insecticides in greenhouse Zinnia and impact on aphid populations. Appl. Eng. Agric. 31:211-216.

DiFonzo, C. D., and Agle, K. 2008. Soybean aphid development on, and BCMV transmission to, Otebo dry bean, Phaseolus vulgaris. Crop Manage. doi:10.1094/CM-2008-0916-01-RS

Dixon, A. F. G. 1998. Aphid Ecology. Chapman and Hall, London, UK.

Douglas, A. E., and van Emden, H. F. 2007. Nutrition and symbiosis. Pages 115-134 in: Aphids as Crop Pests. H. van Emden and R. Harrington, eds. CAB International, Oxfordshire, UK.

Fehr, W. R., and Caviness, C. E. 1977. Stages of soybean development. Coop. Ext. Serv. Special Rep. 80. Iowa State Univ., Ames, IA.

Foster, S. P., Devine, G., and Devonshire, A. L. 2007. Insecticide resistance. Pages 261-286 in: Aphids as Crop Pests. H. van Emden and R. Harrington, eds. CAB Int., Oxfordshire, UK.

Hallett, R. H., Bahlai, C. A., Xue, Y., and Schaafsma, A. W. 2014. Incorporating natural enemy units into a dynamic action threshold for the soybean aphid, Aphis glycines (Homoptera: Aphididae). Pest Manag. Sci. 70:879888.

Hanafi, A., Radcliffe, E. B., and Ragsdale, D. W. 1989. Spread and control of potato leafroll virus in Minnesota. J. Econ. Entomol. 82:1201-1206.

Hill, J. H., Alleman, R., Hogg, D. B., and Grau, C. R. 2001. First report of transmission of Soybean mosaic virus and Alfalfa mosaic virus by Aphis glycines in the New World. Plant Dis. 85:561.

Hodgson, E. W., Burkness, E. C., Hutchison, W. D., and Ragsdale, D. W. 2004. Enumerative and binomial sequential sampling plans for soybean aphid (Homoptera: Aphididae) in soybean. J. Econ. Entomol. 97:21272136.

Hodgson, E. W., McCornack, B. P., Tilmon, K., and Knodel, J. J. 2012. Management recommendations for soybean aphid (Hemiptera: Aphididae) in the United States. J. Integr. Pest Manag. 3:1-10.

Hodgson, E. W., and VanNostrand, G. 2014. Soybean aphid efficacy screening program, 2013. Arthropod Manag. Tests: 39:F46.

Hodgson, E. W., and VanNostrand, G. 2015. Evaluation of insecticides for control of soybean aphid, 2014. Arthropod Manag. Tests 40:F11.

Hodgson, E. W., and VanNostrand, G. 2016. Evaluation of insecticides for control of soybean aphid, 2015. Arthropod Manag. Tests 41:tsw041.

Hurley, T. and Mitchell, P. D. 2014. The value of neonicotinoids in North American agriculture: value of insect pest management to US and Canadian corn, soybean, and canola farmers. AgInfomatics, LLC.

Johnson, K. D., O’Neal, M. E., Ragsdale, D. W., DiFonzo, C. D., Swinton, S. M., Dixon, P. M., Potter, B. E., Hodgson, E. W., and Costamagna, A. C. 2009. Probability of cost-effective management of soybean aphid (Hemiptera: Aphididae) in North America. J. Econ. Entomol. 102:2101-2108.

Kieckhefer, R. W., Gellner, J. L., and Riedell, W. E. 1995. Evaluation of the aphid-day standard as a predictor of yield loss caused by cereal aphids. Agron. J. 87:785-788.

Knodel, J. J., Beauzay, P. B., and Prasifka, P. 2016. Efficacy of foliar-applied sulfoxaflor for control of soybean aphid and impact on lady beetles, 2015 . Arthropod Manag. Tests: 41:tsw060.

Koch, R. L., and Potter, B. D. 2016. Assessing and reporting potential cases of soybean aphid resistance to pyrethroids. Minnesota Crop News. Cooperative Extension, University of Minnesota, St. Paul. http://blog- 
crop-news.extension.umn.edu/2016/08/assessing-and-reporting-potentialcases.html

Lemos Filho, J. P., and Paiva, E. A. S. 2006. The effects of sooty mold on photosynthesis and mesophyll structure of mahogany (Swientia macrophylla King., Meliaceae). Bragantia 65:11-17.

Macedo, T. B., Bastos, C. S., Higley, L. G., Ostlie, K. R., and Madhavan, S. 2003. Photosynthetic responses of soybean to soybean aphid (Homoptera: Aphididae) injury. 2003. J. Econ. Entomol. 96:188-193.

Malumphy, C. P. 1997. Morphology and anatomy of honeydew eliminating organs. Pages 269-274 in: Soft Scale Insects: Their Biology, Natural Enemies and Control, Vol. 7A. Y. Ben-Dov and C. J. Hodgson, eds. Elsevier Science B.V., Amsterdam, The Netherlands.

McCarville, M. T., Soh, D. H., Tylka, G. L., and O'Neal, M. E. 2014. Aboveground feeding by soybean aphid, Aphis glycines, affects soybean cyst nematode, Heterodera glycines, reproduction belowground. PLoS ONE 9:e86415.

McCornack, B. P., Ragsdale, D. W., and Venette. R. C. 2004. Demography of soybean aphid at summer temperatures. J. Econ. Entomol. 97:854-861.

McCornack, B. P., Costamagna, A. C., and Ragsdale, D. W. 2008. Withinplant distribution of soybean aphid (Hemiptera: Aphididae) and development of node-based sample units for estimating whole-plant densities in soybean. J. Econ. Entomol. 101:1488-1500.

Mittler, T. E., and Douglas. A. E. 2003. Honeydew. Pages 523-525 in: Encyclopedia of Insects. V. H. Resh and R. T. Carde, eds. Academic Press, San Diego, CA.

Mueller, E. E., and Grau, C. R. 2007. Seasonal progression, symptom development, and yield effects of Alfalfa mosaic virus epidemics on soybean in Wisconsin. Plant Dis. 91:266-272.

Myers, S. W., Gratton, C., Wolkowski, R. P., Hogg, D. B., and Wedberg. J. L. 2005. Effect of soil potassium availability on soybean aphid (Hemiptera: Aphididae) population dynamics and soybean yield. J. Econ. Entomol. 98:113-120.

Myers, S. W., and Gratton, C. 2006. Influence of potassium fertility on soybean aphid population dynamics at a field and regional scale. Environ. Entomol. 35:219-227.

Nachappa P., Culkin, C. T., Saya II, P. M., Han, J., and Nalam, V. J. 2016. Water stress modulates soybean aphid performance, feeding behavior, and virus transmission in soybean. Front. Plant Sci. 7:552.

Nauen, R., Reckmann, U., Armborst, S., Stupp, H. P., and Elbert, A. 1999. Whitefly-active metabolites of imidacloprid: Biological efficacy and translocation in cotton plants. Pesticide Sci. 55:265-271.

NCSRP. 2013. Soybean Aphid: Field Guide. North Central Soybean Research Program.

http://www.soybeanresearchinfo.com/pdf docs/SoybeanAphid Field Gui de 2013.pdf

Olson, K., Badinbanga, T., and DiFonzo, C. 2008. Farmers' awareness and use of IPM for soybean aphid control: report of survey results for the 2004, 2005, 2006, and 2007 crop years. Staff Paper Series P08-12:1-29.

O’Neal, M., Johnson, K., Hodgson, E., Ragsdale, D., MacRae, I., Potter, B., DiFonzo, C., Tilmon, K., Cullen, E., Glogoza, P., and McCornack, B. P. 2010. Comment on 'Soybean aphid population dynamics, soybean yield loss, and development of stage-specific economic injury levels' by M. A. Catangui, E. A. Beckendorf, and W. E. Riedell 2009. Agron. J. 101:10801092. Agron. J. 102:55-59.

Pettersson, J., Tjallingii, W. F., and Hardie, J. 2007. Host-plant selection and feeding, pp. 87-114. In: H. van Emden and R. Harrington (eds.), Aphids as Crop Pests. CAB International, Oxfordshire, UK

Pedigo, L. P., Hutchins, S. H. and Higley, L. G. 1986. Economic injury levels in theory and practice. Annu. Rev. Entomol. 31:341-368.

Ragsdale, D. W., Voegtlin, D. J. and O'Neil, R. J. 2004. Soybean aphid biology in North America. Ann. Entomol. Soc. Am. 97:204-208.

Ragsdale, D. W., McCornack, B. P., Venette, R. C., Potter, B. D., MacRae, I. V., Hodgson, E. W., O'Neal, M. E., Johnson, K. D., O'Neil, R. J., DiFonzo, C. D., Hunt, T. E., Glogoza, P. A., and Cullen, E. M. 2007. Economic threshold for soybean aphid. J. Econ. Entomol. 100:1258-1267.

Ragsdale, D. W., Landis, D. A., Brodeur, J., Heimpel, G. E., and Desneux, N. 2011. Ecology and management of the soybean aphid in North America. Annu. Rev. Entomol. 56:375-399.

Tilmon, K. J. 2014. Soybean aphid scouting and management. iGrow, 7 August 2014. South Dakota State Univ., Brookings, SD. http://igrow.org/agronomy/soybeans/soybean-aphid-scouting-andmanagement 1

Tilmon, K. J., Hodgson, E. W., O’Neal, M. E., and Ragsdale, D. W. 2011. Biology of the soybean aphid, Aphis glycines (Hemiptera: Aphididae) in the United States. J. Integ. Pest Mngmt. 2:1-7.

Tran, A. K., Alves, T. M., and Koch, R. L. 2016. Potential for sulfoxaflor to improve conservation biological control of Aphis glycines (Hemiptera: Aphididae) in soybean. J. Econ. Entomol. 109:2105-2114.

USDA-NASS 1999. United States Dept. of Agric., National Agric. Statistics Serv. (USDA-NASS). Washington, DC. http://www.nass.usda.gov

USDA-NASS 2005. United States Dept. of Agric., National Agric. Statistics Serv. (USDA-NASS). Washington, DC. http://www.nass.usda.gov

Varenhorst, A. J., and O'Neal, M. E. 2012. The response of natural enemies to selective insecticides applied to soybean. Environ. Entomol. 41:15651574.

Walter, A. J., and DiFonzo, C. D. 2007. Soil potassium deficiency affects soybean phloem nitrogen and soybean aphid populations. Environ. Entomol. 36:26-33.

Wang, Q., Xu W., and Yan S. C. 2011. Research on insecticide resistance of Aphis glycines in Heilongjiang Province. J. Northeast Agric. Univ. 42:137-140.

Wang, R. Y., Kritzman, A., Hershman, D. E., and Ghabrial, S. A. 2006. Aphis glycines as a vector of persistently and nonpersistently transmitted viruses and potential risks for soybean and other crops. Plant Dis. 90:920-926.

Weichel, L., and Nauen, R. 2003. Uptake, translocation and bioavailability of imidacloprid in several hop varieties. Pest Manag. Sci. 60:440-446.

Zhang, W., and Swinton, S. M. 2009. Incorporating natural enemies in an economic threshold for dynamically optimal pest management. Ecol. Model. 220:1315-1324.

Zhang, W., and Swinton, S. M. 2012. Optimal control of soybean aphid in the presence of natural enemies and the implied value of their ecosystem services. J. Environ. Manag. 96:7-16. 